\title{
Thrombin generation in a reconstituted system: a comment.
}

Citation for published version (APA):

Hemker, H. C. (2002). Thrombin generation in a reconstituted system: a comment. Thrombosis and Haemostasis, 87, 551-554. https://doi.org/10.1055/s-0037-1613046

Document status and date:

Published: 01/01/2002

DOI:

10.1055/s-0037-1613046

Document Version:

Publisher's PDF, also known as Version of record

\section{Please check the document version of this publication:}

- A submitted manuscript is the version of the article upon submission and before peer-review. There can be important differences between the submitted version and the official published version of record.

People interested in the research are advised to contact the author for the final version of the publication, or visit the DOI to the publisher's website.

- The final author version and the galley proof are versions of the publication after peer review.

- The final published version features the final layout of the paper including the volume, issue and page numbers.

Link to publication

\footnotetext{
General rights rights.

- You may freely distribute the URL identifying the publication in the public portal. please follow below link for the End User Agreement:

www.umlib.nl/taverne-license

Take down policy

If you believe that this document breaches copyright please contact us at:

repository@maastrichtuniversity.nl

providing details and we will investigate your claim.
}

Copyright and moral rights for the publications made accessible in the public portal are retained by the authors and/or other copyright owners and it is a condition of accessing publications that users recognise and abide by the legal requirements associated with these

- Users may download and print one copy of any publication from the public portal for the purpose of private study or research.

- You may not further distribute the material or use it for any profit-making activity or commercial gain

If the publication is distributed under the terms of Article $25 \mathrm{fa}$ of the Dutch Copyright Act, indicated by the "Taverne" license above, 


\section{Thrombin Generation in a Reconstituted System: A Comment}

In the article of Butenas et al. (1) like in a number of similar publications of these authors on the same subject (2-6), the authors observe a relatively good agreement between the behavior of a model system of the thrombin generating mechanism, reconstructed from a set of purified proteins, and the data obtained from clotting whole blood.

This is an extremely interesting result because it strongly suggests that the model system realistically represents the essence of the physiological mechanism. If this is true, then the data from the model system should automatically also have to be in accordance with observations on thrombin generation in platelet poor and in platelet rich plasma (PPP/PRP).

Comparison with data obtained by others in PPP and PRP therefore should be an essential element in the discussion. In the last decade much new information on thrombin generation in these systems has been obtained by various groups [e. g. (7-12), see (13) for more examples]. However, in the articles of Butenas and coauthors, all references to recent work on thrombin generation in PPP and PRP are carefully avoided.

If we do attempt such a comparison, several discrepancies appear:

The most obvious is that thrombin generation in the reconstituted system with added procoagulant phospholipids (PS/PC) is about three times as high as that in normal plasma. Calculation of prothrombin conversion and thrombin decay from the curves of fig. 1 from (1) using the figures for the concentrations previously published (4) and the algorithm of (14), shows that thrombin is inactivated at about half of the rate observed in fresh normal citrated plasma [i.e. in the absence of heparin, see (15)], despite the presence of purified antithrombin at a concentration that is about 1.4 times higher than the physiological one $(15,16)$. Physiological concentrations of purified proteins obviously do not guarantee physiological activities. Calculation of prothrombin conversion also reveals that the prothrombin present must be (almost) entirely converted into thrombin. In whole blood, according to the same authors (17) $25 \%$ of prothrombin remains unconverted; in our experience in PPP and PRP about 10\% residual prothrombin remains. Under near to physiological conditions prothrombinase activity therefore stops before its substrate, i.e. prothrombin, is exhausted. In the reconstituted system it does not, despite the presence of TFPI, protein $\mathrm{C}$ and thrombomodulin. In normal PPP, even without added TM, the APC system effectively limits the amount of prothrombin converted, as can be judged from the fact that more thrombin is generated in APC resistant plasma than in normal plasma (18). Apparently a phenomenon of recognised pathophysiological importance is not reflected in the reconstituted system. This might, for example, be caused by biological activity of the proteins added and/or the absence of phosphatidyl etha-

Correspondence to: Prof. H. C. Hemker, Cardiovascular Research Institute, Maastricht University, Universiteitssingel 50, P. O. Box 616, NL-6200 MD, Maastricht, The Netherlands - Tel.: +31 43388 1674/75, Fax: +31 43388 4759; E-mail: HC.Hemker@thrombin-com nolamine (PE) that is known to be required for protein $\mathrm{C}$ activation by TM (19). Platelets do contain PE, which may (partly) explain why thrombin generation in the reconstituted system with platelets is so much lower than with added PCPS (Butenas op. cit. figs 1 and 2).

When comparing observations made in fresh PRP with those in the reconstituted system with isolated platelets it strikes that thrombin formation occurs almost immediately. In fresh PRP (7), and in whole blood (8), it is characteristically preceded by a lag time of several minutes, also observed in minimally altered whole blood by the authors et al. (17). During this lag, thrombin mediated reinforcement loops switch on $(7,20)$ and in this respcet PRP is fundamentally different from PPP to which procoagulant phospholipids and TF are added. The mechanism involves platelet receptors GPIIb/IIIa (21) and GPIb in combination with von Willebrand Factor (vWF) and fibrin (22). Its physiological importance is illustrated by the fact that in fresh PRP, thrombin generation is seriously impaired in von Willebrand disease (independent of the concomitant lack of factor VIII) as well as in congenital a- and hypofibrinaemia $(13,22)$. Due comparison to pre-existent literature would have learned that the lag-time tends to disappear when isolated platelet are added back to plasma [cf. figures 5 and 3 in (21)] and gradually disappears by the addition of traces of thrombin or of TF concentrations equal to or higher than that in human brain thromboplasin diluted 1:240 (7), a dilution that roughly corresponds to the $15 \mathrm{pM}$ used by Butenas et al. Probably slight platelet damage during isolation, or TF concentrations above a certain very low level, generates sufficient thrombin to short-circuit one or more of the physiological mechanisms that trigger platelet procoagulant activity. This explains why the activity of the reconstituted system has a superficial resemblance to normal function even in the absence of fibrinogen and von Willebrand factor.

It is known for over half of a century - and reconfirmed in the present article - that the platelet number does not influence the clotting time of blood unless below $\sim 10 \%$ of normal e. g. (23). Extensive experiments on the relation between platelet number and thrombin generation in fresh or reconstituted PRP exist in the literature $(21,24)$. From these results one can deduce that only a small amount of the platelet procoagulant material is required for the onset of thrombin generation. In our experience, even in citrated or ACD PRP, the minimal platelet damage that suffices to facilitate thrombin generation already is observable within two hours after venapuncture. A fortiori, in thrombin generation experiments in which isolated platelets are used, one has to reckon with such damage and a control that determines how much procoagulant phospholipids are present in the unactivated platelet preparation is obligatory. In summary: Maintenance of the claim that the results in the model system of Butenas et al. represent more than a superficial similarity to a physiologically relevant situation would require careful comparison to the body of knowledge on thrombin generation in PPP, PRP and blood as built up in recent years by other groups, as well as control experiments that show 1: Normal activity of the thrombin inhibiting system; 2: Normal activity of the TM-protein C system; 3: Normal activity of the TFPI system; 4: An estimate of procoagulant phospholipids present in the platelet preparation used and 5: Dependency of the system on vWF and fibrinogen. 
H. Coenraad Hemker

Cardiovascular Research Institute Maastricht, Maastricht University, The Netherlands

\section{References}

1. Butenas S, Branda RF, van't Veer C, Cawthern KM, Mann KG. Platelets and phospholipids in tissue factor-initiated thrombin generation. Thromb Haemost 2001; 86: 660-7.

2. Cawthern KM, van't Veer C, Lock JB, DiLorenzo ME, Branda RF, Mann KG. Blood coagulation in hemophilia A and hemophilia C. Blood 1998; 91: 4581-92.

3. Mann KG, van't Veer C, Cawthern K, Butenas S. The role of the tissue factor pathway in initiation of coagulation. Blood Coagul Fibrinolysis 1998; 9 Suppl 1: S 3-7.

4. Butenas S, van't Veer C, Mann KG. "Normal" thrombin generation. Blood 1999; 94: 2169-78.

5. Butenas S, van't Veer C, Cawthern K, Brummel KE, Mann KG. Models of blood coagulation. Blood Coagul Fibrinolysis 2000; 11 Suppl 1: S9-13.

6. Butenas S, Cawthern KM, van't Veer C, DiLorenzo ME, Lock JB, Man KG. Antiplatelet agents in tissue factor-induced blood coagulation. Blood 2001; 97: 2314-22.

7. Beguin S, Lindhout T, Hemker HC. The effect of trace amounts of tissue factor on thrombin generation in platelet rich plasma, its inhibition by heparin. Thromb Haemost 1989; 61: 25-9.

8. Kessels H, Beguin S, Andree H, Hemker HC. Measurement of thrombin generation in whole blood-the effect of heparin and aspirin. Thromb Haemost 1994; 72: 78-83.

9. Prasa D, Svendsen L, Sturzebecher J. Inhibition of thrombin generation in plasma by inhibitors of factor Xa. Thromb Haemost 1997; 78: 1215-20.

10. Prasa D, Svendsen L, Sturzebecher J. The ability of thrombin inhibitors to reduce the thrombin activity generated in plasma on extrinsic and intrinsic activation. Thromb Haemost 1997; 77: 498-503.

11. Herault JP, Dol F, Gaich C, Bernat A, Herbert JM. Effect of clopidogrel on thrombin generatin in platelet-rich plasma in the rat. Thromb Haemost 1999; 81: 957-60.

12. Peyrou V, Lormeau JC, Herault JP, Gaich C, Pfliegger AM, Herbert JM. Contribution of erythrocytes to thrombin generation in whole blood. Thromb Haemost 1999; 81: 400-6.
13. Hemker HC, Beguin S. Phenotyping the clotting system. Thromb Haemost 2000; 84: 747-51.

14. Hemker HC, Willems GM, Beguin S. A computer assisted method to obtain the prothrombin activation velocity in whole plasma independent of thrombin decay processes. Thromb Haemost 1986; 56: 9-17.

15. Beguin S, Kessels H, Dol F, Hemker HC. The consumption of antithrombin III during coagulation, its consequences for the calculation of prothrombinase activity and the standardisation of heparin activity. Thromb Haemost 1992; 68: 136-42.

16. Conard J, Brosstad F, Lie Larsen M, Samama M, Abildgaard U. Molar antithrombin concentration in normal human plasma. Haemostasis 1983; 13: 363-8.

17. Rand MD, Lock JB, van't Veer C, Gaffney DP, Mann KG. Blood clotting in minimally altered whole blood. Blood 1996; 88: 3432-45.

18. Nicolaes GA, Thomassen MC, Tans G, Rosing J, Hemker HC. Effect of activated protein $\mathrm{C}$ on thrombin generation and on the thrombin potential in plasma of normal and APC-resistant individuals. Blood Coagul Fibrinolysis 1997; 8: 28-38.

19. Smirnov MD, Ford DA, Esmon CT, Esmon NL. The effect of membrane composition on the hemostatic balance. Biochemistry 1999; 38: 3591-8.

20. Biggs R, Macfarlane RG. Human Blood Coagulation. Blackwell Scientific Publications 1953; p. 97.

21. Reverter JC, Beguin S, Kessels H, Kumar R, Hemker HC, Coller BS. Inhibition of platelet-mediated, tissue factor-induced thrombin generation by the mouse/human chimeric 7E3 antibody. Potential implications for the effect of c7E3 Fab treatment on acute thrombosis and "clinical restenosis". J Clin Invest 1996; 98: 863-74.

22. Beguin S, Kumar R, Keularts I, Seligsohn U, Coller BS, Hemker HC. Fibrin-dependent platelet procoagulant activity requires GPIb receptors and von Willebrand Factor. Blood 1999; 93: 64-70.

23. Eagle H. Studies on Blood Coagulation. I. The role of Prothrombin and of Platelets in the Formation of Thrombin. J Gen Physiol 1934; 18: 531-45.

24. Galli M, Beguin S, Lindhout T, Hemker CH. Inhibition of phospholipid and platelet-dependent prothrombinase activity in the plasma of patients with lupus anticoagulants. Br J Haematol 1989; 72: 549-55.

Received October 18, 2001 Accepted October 25, 2001

\section{Thrombin Generation in a Reconstituted System: A Reply}

Dear Sir,

The aim of our laboratory is to provide a biologically relevant, quantitative, mechanistic description of the blood coagulation process. Toward this end, we have developed two biological systems, which involve non-anticoagulated, non-chilled whole human blood: a) Phlebotomy blood contact pathway suppressed by corn trypsin inhibitor

Correspondence to: Kenneth G. Mann, Department of Biochemistry, University of Vermont, Given Building Room C401, 89 Beaumont Avenue, Burlington, VT 05405-0068, USA - Tel.: 802-656-0335; Fax: 802-862-8229; E-mail: kmann@zoo.uvm.edu is initiated to clot in vitro by a fixed concentration of a chemically defined tissue factor (TF) preparation (1-6); b) Blood exuding from a microvascular wound is evaluated for composition by sequential sampling $(7,8)$.

We attempt to emulate these biological models using mixtures of highly purified reaction components and examine the individual and combined mechanistic contributions of substrates, intermediates and products in the reaction $(6,9-17)$. Finally, we simulate these reactions using computer-based models employing defined chemical parameters for the individual reactions of the blood coagulation process and its regulation $(18,19)$. Each person has an individual phenotype which may or may not represent mean population values either quantitatively or qualitatively. Therefore we use convergence of results from biological, 